\title{
パネルディスカッション 呼吸困難に対する診断と処置の進歩
}

\section{腫瘍による気道狭窄の評価とその対策}

喉頭部腫瘍による気道狭窄が原因となる呼吸 困難に対しては，腫瘍に対する治療全体を考慮 して対応する必要がある。気道狭窄による呼吸 困難の評価を検討するために，1983年から1992 年の 10 年間の腫瘍による上気道狭窄に対して気 管切開（気切）を施行した78例について，選択 例39例と緊急例39例に分けて比較した。

今回の検討では，気切の必要性を認めて24時 間以内に施行した例を緊急例と分類した。78例 の原発部位は喉頭・下咽頭が多く，口腔・甲状 腺と続いている（表 1 )。

Bedsideで気切を行った 8 例は，呼吸困難を 正確に評価し得なかった例と思われる。この 8 例の気切の原因は腫瘍の増大や局所の浮腫によ る狭窄の増悪のほかに, 腫瘍よりの出血, 中枢 病変，肺炎などであった。

狭窄の程度を評価するために高圧 X 線上の 気道の狭窄度を正面と側面像で，狭窄部の長さ と最短部の幅を測定し，その分布と平均值を調 べた（表 2 )。正面・側面像ともに緊急例の方が

表 1 気管切開例の原発部位別分類

\begin{tabular}{|c|c|c|c|c|}
\hline \multirow{2}{*}{ 部位 } & \multirow{2}{*}{ 選択的 } & & 急 & \multirow{2}{*}{ 計 } \\
\hline & & 手術室 & Bedside & \\
\hline 口＼cjkstart腔 & 6 & 0 & 2 & 8 \\
\hline 上 顎 & 0 & 1 & 2 & 3 \\
\hline 上咽頭 & 1 & 2 & 1 & 4 \\
\hline 中咽頭 & 1 & 4 & 1 & 6 \\
\hline 下咽頭 & 11 & 2 & 0 & 13 \\
\hline 喉 頭 & 16 & 15 & 1 & 32 \\
\hline 甲状腺 & 3 & 5 & 0 & 8 \\
\hline 気管・縦隔 & 1 & 2 & 1 & 4 \\
\hline \multirow[b]{2}{*}{ 計 } & \multirow[b]{2}{*}{39} & 31 & 8 & \multirow[b]{2}{*}{78} \\
\hline & & \multicolumn{2}{|c|}{39} & \\
\hline
\end{tabular}

九州大学医学部耳鼻咽喉科
冨田吉信，山本 智矢

表 2 高圧 $\mathrm{X}$ 線上の気道狭窄の程度

\begin{tabular}{|c|c|c|c|c|}
\hline & \multicolumn{2}{|c|}{ 正面 } & \multicolumn{2}{|c|}{ 側面 } \\
\hline & $\begin{array}{l}\text { 幅 } \\
\text { (平均) }\end{array}$ & $\begin{array}{l}\text { 長さ } \\
\text { (平均) }\end{array}$ & $\begin{array}{l}\text { 幅 } \\
\text { (平均) }\end{array}$ & $\begin{array}{l}\text { 長さ } \\
\text { (平均) }\end{array}$ \\
\hline $\begin{array}{l}\text { 選 } \\
\text { 択 } \\
\text { 例 }\end{array}$ & $\begin{array}{l}0 \sim 5 \mathrm{~mm} \\
(3.5)\end{array}$ & $\begin{array}{l}0 \sim 20 \mathrm{~mm} \\
(13)\end{array}$ & $\begin{array}{l}0 \sim 8 \mathrm{~mm} \\
(4.8)\end{array}$ & $\begin{array}{l}10 \sim 25 \mathrm{~mm} \\
(14)\end{array}$ \\
\hline $\begin{array}{l}\text { 緊 } \\
\text { 急 } \\
\text { 例 }\end{array}$ & $\begin{array}{l}0 \sim 5 \mathrm{~mm} \\
(2.5)\end{array}$ & $\mid \begin{array}{l}0 \sim 50 \mathrm{~mm} \\
(26)\end{array}$ & $\left(\begin{array}{l}0 \sim 8 \mathrm{~mm} \\
(3.5)\end{array}\right.$ & $\begin{array}{l}10 \sim 50 \mathrm{~mm} \\
(23)\end{array}$ \\
\hline
\end{tabular}

表 3 気道狭窄による呼吸困難の評価

1. 狭 窄 部

(1) 狭窄の程度（長さ, 幅) (腫場の増大傾向)

(2) 気道粘膜の性状（炎症・感染・出血）

2. 関連領域

(1) 腫瘍よりの出血の可能性

(2) 痰・唾液の粘稠度

(3) 誤嚥の有無

(4) 下気道の炎症・感染

3. 全 身

(1) 動脈血液ガス分析

(2) 睡眠時の呼吸動態変化

(3) 中枢病変の有無

(4) 意識レベル

(5) 年噛

幅は短く, 長さは長かった。呼吸困難の程度を 客観的に示す気切前の動脈血酸素分圧の平均値 は選択例 $82.4 \mathrm{mmHg}$, 緊急例 $74.0 \mathrm{mmHg}$ と緊 急例で低かった。

これらの検討より，気道狭窄による呼吸困難 の評価項目を狭窄部, 関連領域, 全身の 3 群に 分けて表 3 に示した。対策としては，腫瘍に対 する術前治療の期間の長さや，患者の苦痛・自 由度を考慮すると気切可能例は, 早期に気切を 行うのが適当と思われた。 